\title{
PENGARUH PERTUMBUHAN EKONOMI DAN PERTUMBUHAN PENDUDUK TERHADAP TINGKAT PARTISIPASI ANGKATAN KERJA DI KOTA LHOKSEUMAWE PERIODE 2007-2015
}

\author{
Cut Putri Mellita Sari ${ }^{\mathrm{a} 1}$, Putri Susanti ${ }^{\mathrm{a} 2}$ \\ ${ }^{a}$ Fakultas Ekonomi dan Bisnis Universitas Malikussaleh \\ 1Corresponding author: cmellita0674@gmail.com \\ 2 putrisusanti1410@gmail.com
}

\section{A R T I C L E I N F O R M A T I O N}

Keywords: Labor Force Participation Rate (LFPR), Economic Growth, Population Growth.

\section{A B S T R A C T}

This study aims to determine the effect of economic growth and population growth on labor force participation rate (LFPR) in Lhokseumawe city from 2007 to 2015. The data used in this study is secondary data obtained from the Central Bureau of Statistics (BPS). Data analysis method used in this research is Multiple Linear regression model. The results partially show that economic growth has a positive and significant effect on labor force participation rate (LFPR). The and population growth has a positive and significant effect on labor force participation rate (LFPR). Simultaneously indicates that economic growth and population growth have a positive and significant effect on labor force participation rate (LFPR) in Lhokseumawe City from 2007 to 2015.

\section{PENDAHULUAN}

Tingkat Partisipasi Angkatan Kerja (TPAK) merupakan seberapa banyak keikutsertaan orang atau masyarakat dalam menjelaskan tentang penduduk yang mampu melakukan kegiatan produksi (Mankiw, 2013).

Dimana dengan adanya kegiatan ekonomi dalam memproduksi suatu barang, maka akan memperbanyak lapangan pekerjaan sehingga didalamnya sangat menuntut keterlibatan banyak orang. Oleh karena itu, pihak program pembangunan membutuhkan harapan-harapan yang baru, yaitu harapan untuk dapat ikut menikmati hasil pembangunan serta dapat berada dalam kegiatan tersebut, dengan demikian tingkat partisipasi angkatan kerja akan semakin besar pula (Simanjuntak, 2000).

Di Kota Lhokseumawe tingkat partisipasi angkatan kerjanya selalu dalam keadaan naik turun atau bersifat fluktuatif, sehingga menyebabkan jumlah angkatan kerja yang terdapat di Kota Lhokseumawe tidak stabil. Hal ini dipengaruhi oleh batas umur, pendidikan, kegiatan ekonomi, upah, jenis kelamin, jumlah penduduk, dan tingkat pengangguran (Simanjuntak, 2000). Apabila keadaan seperti ini terjadi secara berkepanjangan maka akan mengakibatkan tingginya tingkat pengangguran. Ditambah lagi dengan jumlah penduduk yang terdapat di Kota Lhokseumawe selalu saja meningkat setiap tahunnya (BPS, 2016).

Pertumbuhan penduduk yang besar akan menciptakan jumlah angkatan kerja yang besar pula di pasar tenaga kerja.

Bertambahnya angkatan kerja yang tidak disertai dengan lowongan atau kesempatan kerja akan menimbulkan pengangguran. Dengan semakin banyaknya tingkat pengangguran maka pertumbuhan ekonomi di wilayah tersebut pun akan menurun (Jhingan, 2010).

Untuk lebih rincinya dapat diperhatikan pada Tabel 1 mengenai perkembangan tingkat partisipasi angkatan kerja, pertumbuhan ekonomi dan pertumbuhan penduduk yang terdapat di Kota Lhokseumawe periode 2007-2015, sebagai berikut: 
Tabel 1

Data Pertumbuhan Ekonomi, Pertumbuhan

Penduduk dan Tingkat Partisipasi Angkatan

Kerja di Kota Lhokseumawe Periode 2007-2015

\begin{tabular}{|c|c|c|c|}
\hline TAHUN & $\begin{array}{c}\text { TPAK } \\
(\%)\end{array}$ & $\begin{array}{c}\text { Pertumbuhan } \\
\text { Ekonomi } \\
(\%)\end{array}$ & $\begin{array}{c}\text { Pertumbuhan } \\
\text { Penduduk } \\
(\%)\end{array}$ \\
\hline 2007 & 61,42 & 12,11 & 1,24 \\
\hline 2008 & 52,32 & 6,38 & 1,03 \\
\hline 2009 & 54,61 & 5,66 & 0,68 \\
\hline 2010 & 57,73 & 5,88 & 7,49 \\
\hline 2011 & 62,07 & 3,79 & 2,29 \\
\hline 2012 & 55,34 & 4,35 & 2,70 \\
\hline 2013 & 56,77 & 3,50 & 1,21 \\
\hline 2014 & 59,1 & 6,7 & 3,01 \\
\hline 2015 & 59,38 & 8,73 & 2,11 \\
\hline
\end{tabular}

Sumber: Badan Pusat Statistik (BPS). 2016

Dari Tabel 1 diatas menunjukkan bahwa pada tahun 2009 dan tahun tahun 2011 tingkat partisipasi angkatan kerjanya meningkat dari tahun sebelumnya, tetapi pertumbuhan ekonominya malah menurun, hal ini dapat dilihat dari tahun 2008 ke tahun 2009, dan dari tahun 2010 ke tahun 2011. Berarti permasalahan yang terjadi pada tahun 2009 dan tahun 2011 berbanding terbalik dengan teori yang dikemukakan oleh (Simanjuntak, 2000) yang menyatakan bahwa kegiatan ekonomi sangat dipengaruhi oleh tingkat partisipasi angkatan kerja. Dimana dengan adanya suatu kegiatan ekonomi maka akan menuntut keterlibatan lebih banyak orang di pasar tenaga kerja, sehingga akan memberikan keuntungan atau hasil untuk dinikmati pula. Jadi semakin bertambahnya kegiatan ekonomi maka semakin besar pula tingkat partisipasi angkatan kerja.

Sehingga dapat disimpulkan dengan tingginya pertumbuhan ekonomi maka akan mengakibatkan tingginya tingkat partisipasi angkatan kerjanya juga, begitu juga sebaliknya semakin berkurangnya kegiatan ekonomi maka penurunan terhadap pertumbuhan ekonomi pun akan terjadi. Dengan demikian apabila pertumbuhan ekonominya menurun maka tingkat pastisipasi angkatan kerjanya juga akan berkurang.

Kemudian pada tahun 2009, 2011, 2013 dan tahun 2015 pertumbuhan penduduknya menurun tetapi tingkat partisipasi angkatan kerjanya meningkat dari tahun sebelumnya. Hal ini juga berbanding terbalik dengan teori yang dinyatakan oleh Sukirno (2007) yang menyatakan bahwa angkatan kerja adalah jumlah tenaga kerja pada suatu waktu disuatu perekonomian. Jumlah angkatan kerja pada setiap tahunnya selalu meningkat maka akan berdampak pada tingkat partisipasi angkatan kerja, baik itu dalam upaya mencari pekerjaan maupun dalam upaya membuka berbagai lapangan pekerjaan sehingga dapat menampung banyaknya jumlah tenaga kerja.

Penelitian ini memiliki perbedaan dengan penelitan-penelitian yang pernah dilakukan sebelumnya. Seperti yang dilakukan oleh Safuridar (2017) yang meneliti tentang pengaruh pertumbuhan ekonomi dan jumlah penduduk terhadap tingkat pengangguran di Kabupaten Aceh Timur dan Nurvita Sari (2016) yang meneliti tentang pengaruh pertumbuhan ekonomi, pertumbuhan penduduk dan produktivitas tenaga kerja terhadap penyerapan tenaga kerja di Kota Jambi. Kedua penelitian tersebut memiliki perbedaan dengan penelitian pada variabel terikat, dimana penelitian ini menggunakan variabel dependent Tingkat Partisipati Angkatan Kerja (TPAK) serta lokasi penelitian dimana penelitian ini dilakukan di Kota Lhokseumawe. Kemudian penelitian yang dilakukan oleh Wisna Sarsi, dkk (2014) yang meneliti pengaruh tingkat upah dan pertumbuhan ekonomi terhadap tingkat partisipasi angkatan kerja di Provinsi Riau dan Nilatus Syaadah (2014) yang meneliti tentang analisis dampak pertumbuhan penduduk terhadap penyerapan angkatan kerja. Kedua penelitian yang telah dilakukan tersebut juga berbeda dimana penelitian ini menambahkan penggunaan variabel terikat yaitu pertumbuhan penduduk dan pertumbuhan ekonomi.

Berdasarkan uraian diatas maka penulis tertarik untuk meneliti lebih lanjut mengenai fenomena yang terdapat di Kota Lhokseumawe dalam sebuah judul penelitian "Pengaruh Pertumbuhan Ekonomi dan Pertumbuhan Penduduk Terhadap Tingkat Partisipasi Angkatan Kerja (TPAK) di Kota Lhokseumawe Periode 2007-2015".

Berdasarkan penguraian diatas, perumusan masalah dalam penelitian ini adalah seberapa besar 
pengaruh pertumbuhan dan pertumbuhan penduduk ekonomi terhadap tingkat partisipasi angkatan kerja (TPAK) di kota Lhokseumawe periode 2007-2015. Sedangkan adapun tujuan dalam penelitian ini untuk mengetahui seberapa besar pengaruh pertumbuhan ekonomi dan pertumbuhan penduduk terhadap tingkat partisipasi angkatan kerja (TPAK) di kota Lhokseumawe periode 2007-2015.

\section{TINJAUAN TEORITIS}

\section{Tingkat Partisipasi Angkatan Kerja (TPAK)}

Menurut Badan Pusat Statistik atau BPS (2012), Tingkat Partisipasi Angkatan Kerja (TPAK) adalah besaran terhadap keseimbangan penduduk yang termasuk dalam usia kerja dipasar tenaga kerja, yang bekerja maupun mencari pekerjaan, yang memberikan persediaan terhadap para kerja dalam mengelola hasil alam yang ada.

Menurut Mulyadi (2003), Tingkat Partisipasi Angkatan Kerja (TPAK) adalah menjelaskan tentang banyaknya penduduk yang dikatakan angkatan kerja dalam kumpulan tertentu untuk membandingi kelompok umur tersebut. Sehingga disimpulkan bahwa Tingkat Partisipasi Angkatan Kerja (TPAK) adalah seseorang dalam usia bekerja yang terdapat dalam pasar yang mampu mengolah barang dan jasa dalam suatu kegiatan sehari-hari guna untuk memperoleh pendapatan yang lebih baik lagi demi tercapainya tingkat kesejahteraan masyarakat.

\section{Pertumbuhan Ekonomi}

Pembangunan ekonomi merupakan kemampuan usaha yang dimiliki dalam suatu perekonomian untuk mengembangkan kegiatan ekonomi demi terwujudnya infrastruktur, dan tingkat pendidikan yang semakin tinggi dengan adanya kemajuan teknologi yang ada. Dengan harapan adanya kesempatan kerja semakin bertambah, maka pendapatan masyarakat pun akan lebih baik seiring dengan tercapainya kemakmuran masyarakat (Sukirno, 2006).

Menurut Prof Simon Kuznets dalam Jhingan (2004), pertumbuhan ekonomi diartikan sebagai proses naiknya kemampuan dalam menghasilkan barang-barang ekonomi kepada penduduk dalam waktu yang lama. Dengan demikian Pertumbuhan ekonomi adalah perubahan yang terjadi terhadap kegiatan ekonomi dalam hal menghasilkan barang dan jasa lebih banyak atau meningkat seiring dengan tercapainya kemakmuran masyarakat.

\section{Pertumbuhan Penduduk}

Penduduk merupakan alat utama pada sebuah usaha untuk menambah hasil produksi dan dapat mengembangkan suatu kegiatan ekonomi. Dengan adanya penduduk maka suatu usaha baru bisa dilakukan dengan baik dan benar. Penduduk di bidang bisnis dan di dunia sekarang sangat menjadi prioritas utama, karena dalam menyediakan tenaga kerja yang diperlukan untuk menciptakan kegiatan ekonomi. Selain itu, konsumsi dari penduduk akan menciptakan permintaan agregat yang memicu kegiatan produksi.

Menurut Mulyadi (2002), pertumbuhan penduduk merupakan perubahan yang menyebabkan jumlah penduduk bisa bertambah maupun berkurang. Perkembangan penduduk sangat dipengaruhi oleh banyaknya kelahiran di suatu wilayah seiring juga dengan banyaknya kematian yang memperkecil banyaknya penduduk.

Dan pertumbuhan penduduk juga dapat diartikan sebagai perubahan jumlah penduduk yang terdapat di dalam wilayah yang berbeda dengan tahun sebelumnya. Jika lebih banyaknya penduduk yang di suatu wilayah, maka akan mendorong peningkatan terhadap pengangguran. Hal ini disebabkan lowongan yang tersedia tidak sesuai dengan pertambahan penduduk yang ada (Subandi, 2011). Oleh karena itu pertumbuhan penduduk adalah suatu perubahan yang menyebabkan orangorang di suatu tempat akan bertambah ataupun berkurang.

\section{METODE PENELITIAN}

\section{Objek dan Lokasi Penelitian}

Objek dalam penelitian ini menggunakan variabel Pertumbuhan Ekonomi $\left(\mathrm{X}_{1}\right)$ dan Pertumbuhan Penduduk $\left(\mathrm{X}_{2}\right)$ sebagai variabel bebas atau independent. Dan variabel Tingkat Partisipasi Angkatan Kerja (Y) sebagai variabel terikat atau dependent. Adapun lokasi penelitian ini dilakukan di Kota Lhokseumawe. 


\section{Jenis dan Sumber Data}

Jenis data dalam penelitian ini menggunakan data sekunder. Data sekunder adalah data yang diperoleh dari pihak ketiga yang telah diteliti sebelumnya. Adapun data yang dibutuhkan dalam penelitian ini adalah data pertumbuhan ekonomi di Kota Lhokseumawe tahun 2007-2015, data pertumbuhan penduduk di Kota Lhokseumawe tahun 2007-2015, dan data tingkat partisipasi angkatan kerja di Kota Lhokseumawe tahun 20072015. Kemudian data tersebut diinterpolasikan dalam bentuk bulanan atau monthly dengan menggunakan program Eviews.

Adapun sumber data yang diperoleh dalam penelitian ini adalah bersumber dari Badan Pusat Statistik (BPS) di Kota Lhokseumawe, selain itu data-data dalam penelitian ini juga diperoleh dari berbagai bahan-bahan tertulis lainnya, seperti jurnal ilmiah, kajian-kajian literatur, penelitianpenelitian terdahulu yang berkaitan dengan masalah yang diteliti serta studi internet yang menunjang atau yang mendukung penelitian ini.

\section{Teknik Pengumpulan Data}

Teknik pengumpulan data dalam penelitian ini melalui studi perpustakaan (library Research), dokumentasi dan internet. Studi pustaka dilakukan dengan mempelajari skripsi serta jurnal-jurnal untuk mendapatkan informasi yang berhubungan dengan permasalahan yang diteliti dan buku-buku yang ada kaitannya dengan penulisan skripsi ini. Teknik dokumentasi dilakukan dengan cara mendokumentasikan atau mengarsipkan data-data dan informasi yang berkaitan dengan objek penelitian.

\section{Definisi Operasionalisasi Variabel}

Definisi operasional variabel adalah suatu definisi yang diberikan kepada suatu variabel dengan cara memberikan arti dari variabel penelitian, ataupun memberikan suatu operasional yang diperlukan untuk mengukur variabel tersebut (Gujarati, 2003). Operasionalisasi variabel dibuat agar penelitian dapat lebih mudah dipahami sekaligus untuk dapat menghindari terjadinya salah pengertian atau kekeliruan dalam mengartikan variabel yang diteliti, serta operasionalisasi variabel dilakukan untuk memberikan batasan-batasan terhadap variabelvariabel yang digunakan. Dalam penelitian ini menggunakan variabel pertumbuhan ekonomi dan variabel pertumbuhan penduduk sebagai variabel bebas (independent) dan variabel tingkat partisipasi angkatan kerja sebagai variabel terikat (dependent).

\section{Tingkat partisipasi angkatan kerja (Y)}

Tingkat partisipasi angkatan kerja adalah ukuran proporsi penduduk usia kerja yang terlibat aktif dipasar tenaga kerja, baik dengan bekerja atau mencari pekerjaan, yang memberikan ukuran relatif dari pasokan tenaga kerja yang tersedia untuk terlibat dalam produksi barang dan jasa dengan satuan persentase $(\%)$.

\section{Pertumbuhan ekonomi $\left(\mathrm{X}_{1}\right)$ \\ Pertumbuhan ekonomi \\ adalah} perkembangan kegiatan dalam perekonomian yang menyebabkan barang dan jasa yang diproduksi dalam masyarakat bertambah atau meningkat serta kemakmuran masyarakat juga meningkat dengan satuan persentase (\%).

\section{Pertumbuhan penduduk $\left(\mathrm{X}_{2}\right)$}

Pertumbuhan penduduk adalah terjadinya perubahan jumlah penduduk yang ada di suatu wilayah, baik bertambah maupun berkurang yang dipengaruhi oleh faktor kelahiran, kematian dan migrasi dengan satuan persentase $(\%)$.

\section{Metode Analisis Data}

Metode analisis data yang digunakan dalam penelitian ini adalah metode kuantitatif atau data time series yaitu data dalam kurun waktu tertentu, digunakan untuk mempermudah perhitungannya dengan menggunakan data-data statistik. Untuk melihat pengaruh pertumbuhan ekonomi dan pertumbuhan penduduk terhadap tingkat partisipasi angkatan kerja di Kota Lhokseumawe digunakan model regresi linier berganda dengan bantuan program Eviews. Adapun model regresi linier berganda dalam penelitian ini adalah sebagai berikut:

$$
\mathbf{Y}=\boldsymbol{\beta}_{\mathbf{0}}+\boldsymbol{\beta}_{1} \mathbf{X}_{1}+\boldsymbol{\beta}_{2} \mathbf{X}_{2}+\mathbf{e}
$$

\section{Dimana :}

$\mathrm{Y} \quad=$ Tingkat Partisipasi Angkatan Kerja

$\beta_{0}=$ Konstanta 
$\beta_{1}, \beta_{2}=$ Koefisien Regresi Variabel

$\mathrm{X}_{1}=$ Pertumbuhan Ekonomi

$\mathrm{X}_{2}=$ Pertumbuhan Penduduk

e $\quad=$ Variabel Pengganggu (Error term)

Untuk mengukur pengaruh antara variabel digunakan beberapa langkah pengujian. Yaitu pengujian asumsi klasik dan pengujian statistik.

\section{a. Pengujian Asumsi Klasik}

Menurut (Gudono, 2011), uji asumsi klasik disebut juga dengan analisis residul. Disebut demikian karena penelitian mengenai pelanggaran terhadap asumsi klasik biasanya dilakukan dengan mengamati pola nilai residual. Uji asumsi klasik dilakukan untuk mencegah timbulnya masalah dalam analisis regresi linier berganda seperti autokorelasi, heteroskedastisitas serta multikolinieritas.

\section{b. Uji Autokorelasi}

Uji autokorelasi dilakukan untuk mengetahui adakah pada suatu model terdapat hubungan antara kesalahan pengganggu pada tahun sekarang atau tahun $t$ dengan kesalahan pengganggu pada tahun sebelumnya atau t-1 (Ghozali, 2011). Jika pada suatu model terdapat hubungan antara kesalahan pengganggu pada tahun sekarang dengan kesalahan pengganggu pada tahun sebelumnya, maka hal tersebut dinamakan adanya terjadi autokorelasi.

Pengujian terhadap autokorelasi dapat diuji dengan Metode Bruesch-Godfrey nama lain dari uji BG ini adalah uji langrange multiplier (LM test atau pengganda langrange). Apabila $O b s^{*} R$ squared < dari Chi-Square Table $\left(X^{2}\right)$ maka tidak ada terjadinya autokorelasi begitu juga sebaliknya apabila $O b s^{*} R$-squared > dari Chi-Square Table $\left(X^{2}\right)$ maka ada terjadinya autokorelasi dilihat pada 5\% (Widarjono, 2013).

\section{c. Uji Heteroskedastisitas}

Uji heteroskedastisitas adalah suatu kondisi dimana semua gangguan yang terdapat dalam fungsi regresi yang ada tidak mempunyai varians yang sama. Jika ada varians yang sama maka hal itu dinamakan dengan heteroskedastisitas, dan jika ada varians yang beda maka dinamakan dengan homoskedastisitas (Ghozali, 2012). Adapun cara untuk melihat ada atau tidaknya heteroskedastisitas yaitu melalui White Heteroskedastisitas pada program Eviews, dengan nilai $O b s^{*} R$-squared dan Chi-Square Table $\left(X^{2}\right)$. Apabila $O b s^{*} R$-squared < dari Chi-Square Table $\left(X^{2}\right)$ maka tidak ada terjadinya autokorelasi begitu juga sebaliknya apabila $O b s^{*} R$-squared > dari Chi-Square Table $\left(X^{2}\right)$ maka ada terjadinya autokorelasi dilihat pada $\quad 5 \% \quad$ (Widarjono, 2013).

\section{d. Uji Multikolinieritas}

Uji multikolinearitas bertujuan untuk menguji apakah pada suatu model regresi terdapat hubungan antara variabel bebas yang satu dengan variabel bebas yang lainnya (Ghozali, 2006). Jika pada suatu model terdapat hubungan antar variabel bebasnya, maka hubungan inilah yang disebut dengan multikolinieritas. Suatu model yang baik yaitu model yang tidak terkena multikolinieritas antar variabel bebasnya.

Untuk menguji ada tidaknya multikolinieritas dengan cara melihat nilai Variansi Inflation Factors (VIF) dan Tolerance dari masing-masing variabel bebas terhadap variabel terikat. Apabila nilai VIF dibawah 10 dan tolerance value diatas 0,10 , maka model tersebut dapat dikatakan terbebas dari multikolinieritas (Gudono, 2012).

\section{e. Pengujian Hipotesis}

Uji ini dipakai untuk melihat apakah variabel independen secara individu dan bersamasama berpengaruh signifikan terhadap variabel dependen. Uji statistik ini meliputi Uji t, Uji F, Koefisien Determinasi (R ) dan Koefisien Korelasi (R).

\section{f. Uji Siginifikansi Parsial (Uji t)}

Menurut Gujarati (2003) uji t dilakukan untuk menguji apakah ada atau tidaknya pengaruh antara variabel-variabel bebas terhadap variabel terikat secara individu atau parsial. Pengujian hipotesis terhadap koefisien regresi secara parsial dilakukan dengan menggunakan uji $\mathrm{t}$ terhadap 
tingkat keyakinan 95\%, dan tingkat kesalahan 5\% dengan ketentuan degree of freedom $(\mathrm{df})=\mathrm{n}-\mathrm{k}$, dimana $\mathrm{n}=$ jumlah sampel, $\mathrm{k}=$ jumlah variabel.

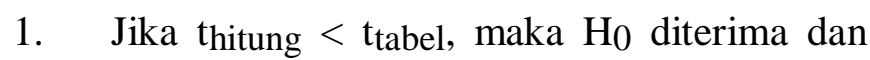
$\mathrm{H}_{1}$ ditolak, artinya secara individual tidak ada pengaruh antara variabel independen terhadap variabel dependen.

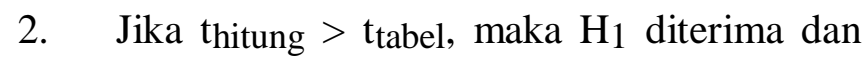
$\mathrm{H}_{0}$ ditolak, artinya secara individual ada pengaruh antara variabel independen terhadap variabel dependen.

\section{g. Uji Signifikansi Simultan (Uji F)}

Menurut Ghozali (2005) uji F dilakukan untuk menguji apakah ada atau tidaknya pengaruh antara variabel-variabel bebas secara bersamasama atau simultan terhadap variabel terikat. Pengujian secara keseluruhan ini dilakukan dengan cara membandingkan nilai antara Fhitung dan Ftabel pada df1 = k-1 dan df $2=\mathrm{n}-\mathrm{k}$ pada derajat keyakinan $95 \%$ atau $=0,05$ dengan kriteria sebagai berikut:

1. Jika Fhitung $<\mathrm{F}_{\text {tabel}}$, yang berarti secara bersama-sama variabel independen tidak berpengaruh terhadap variabel dependen.

2. Jika Fhitung $>F_{\text {tabel, }}$ yang berarti secara bersama-sama variabel independen berpengaruh terhadap variabel dependen.

\section{h. Koefisien Determinasi $\left(\mathbf{R}^{\mathbf{2}}\right)$}

Koefisien determinasi (Adjusted $\mathrm{R}^{2}$ ) dilakukan untuk melihat sejauh mana model ini berpengaruh antara variabel independen dalam menjelaskan variabel dependen. Yang termasuk nilai koefisien determinasi yaitu nilai dari nol sampai dengan satu. Dimana apabila nilainya yang dihasilkan mendekati satu yang artinya variabel independen hampir memberikan semua informasi yang diinginkan terhadap dugaan dari variabel dependennya (Ghozali, 2012).

Sedangkan menurut Gujarati (2003) koefisien determinasi $\left(\mathrm{R}^{2}\right)$ digunakan untuk mengukur proporsi (bagian) atau persentase total varian dalam $\mathrm{Y}$ yang dijelaskan dalam model regresi. Batasannya adalah $0 r^{2} 1$. Apabila nilai $r^{2}$ yang diperoleh sebanyak 1 maka artinya suatu hubungan yang dimiliki sangat baik atau sangat sesuai, dan apabila nilai $\mathrm{r}^{2}$ yang dimiliki sebanyak 0 maka artinya hubungan yang dimilikinya tidak baik atau tidak sesuai.

\section{i. Koefisien Korelasi (R)}

Menurut Supranto (2009) koefisien korelasi merupakan suatu langkah yang dilakukan untuk melihat seberapa kuat atau tidaknya pengaruh variabel independen (X) terhadap variabel dependen (Y). Adapun cara yang dilakukan untuk melihat seberapa kuat atau tidaknya itu dilihat dari hasil yang diperolehnya, jika hasil yang diperolehnya mendekati angka 1 maka artinya pengaruh yang dimilikinya sangat kuat begitu juga sebaliknya.

\section{HASIL PENELITIAN DAN PEMBAHASAN}

\section{Tingkat Partisipasi Angkatan Kerja}

Tingkat Partisipasi Angkatan Kerja (TPAK) adalah besaran terhadap keseimbangan penduduk 15 tahun keatas yang berada dipasar tenaga kerja, yang bekerja maupun mencari pekerjaan, yang dapat menyediakan atau menghasilkan barang dan jasa. Banyaknya angkatan kerja dilihat dari berapa persenkah orang yang menjadi angkatan kerja.

Tingkat Partisipasi Angkatan Kerja (TPAK) Kota Lhokseumawe tahun 2014 adalah 59,1. Adapun indikator yang menunjukkan pasokan tenaga kerja yang bekerja meningkat dari tahun sebelumnya yang mencapai 56,77. Tingkat partisipasi angkatan kerja penduduk yang memiliki jenis kelamin wanita lebih kecil daripada penduduk yang berjenis laki-laki yaitu 39,88 banding 78,96. Karena penduduk yang laki-laki lebih utama yang mempunyai tanggungjawab dalam mencari nafkah. Sehingga TPAK laki-laki lebih tinggi.

Besaran Tingkat Kesempatan Kerja atau TKK Kota Lhokseumawe pada tahun 2014 adalah 93,36 menggambarkan persentase angkatan kerja yang aktif bekerja. Sedangkan angkatan kerja yang sedang mencari pekerjaan, mempersiapkan usaha, merasa putus asa, dan baru akan memulai bekerja, atau disebut penggangguran terbuka sebesar $6,64 \%$. 
Berdasarkan hasil dari Sakernas, Penduduk Kota Lhokseumawe yang dikatakan angkatan kerja yaitu yang telah berusia 15 tahun keatas adalah sejumlah 128.459 jiwa. Dari sejumlah ini, 75,51 persennya tinggal di perkotaan dan selebihnya tinggal di pedesaan. Sebagian besar penduduk (60\%) yang bekerja di Kota Lhokseumawe berstatus buruh, karyawan, pegawai, 27 persen berstatus berusaha sendiri, dan paling sedikit berstatus pekerja bebas seperti di bidang pertanian maupun non-pertanian.

\section{Tabel 2}

Perkembangan Tingkat Partisipasi Angkatan Kerja di Kota Lhokseumawe Periode 2007-2015

\begin{tabular}{|c|c|}
\hline TAHUN & $\begin{array}{c}\text { TPAK } \\
\text { (\%) }\end{array}$ \\
\hline 2007 & 61,42 \\
\hline 2008 & 52,32 \\
\hline 2009 & 54,61 \\
\hline 2010 & 57,73 \\
\hline 2011 & 62,07 \\
\hline 2012 & 55,34 \\
\hline 2013 & 56,77 \\
\hline 2014 & 59,1 \\
\hline 2015 & 59,38 \\
\hline Sumber: Badan Pusat Statistik (BPS), 2016
\end{tabular}

Berdasarkan Tabel 2 dapat dilihat bahwa TPAK di Kota Lhokseumawe pada tahun 2007 sebesar 61,42\%, kemudian pada tahun 2008 tingkat partisipasi angkatan kerjanya menurun menjadi 52,32\%. Pada tahun 2009 sampai dengan tahun 2011 tingkat partisipasi angkatan kerjanya meningkat, kemudian pada tahun 2012 tingkat partisipasi angkatan kerjanya kembali menurun dari $62,07 \%$ menjadi $55,34 \%$. Dan selanjutnya pada tahun 2013 sampai dengan tahun 2015 tingkat partisipasi angkatan kerjanya kembali meningkat. Dengan demikian, dapat disimpulkan bahwa tingkat partisipasi angkatan kerja yang terjadi di Kota Lhokseumawe dari tahun 20072015 bergerak secara fluktuatif.

\section{Pertumbuhan Ekonomi}

Pertumbuhan

Ekonomi adalah perkembangan yang dapat dilakukan untuk mewujudkan adanya pembangunan ekonomi di suatu negara. Pertumbuhan ekonomi melihat seberapajauh sudah kegiatan ekonomi dalam memproduksi barang dan jasa yang nantinya dapat memperbanyak pendapatan masyarakat pada tahun tertentu. Dan apabila di suatu wilayah kegiatan ekonomi yang dilakukan dapat berjalan dengan baik dan sesuai dengan sasaran maka secara otomatis pembangunan ekonomi yang ada akan tercipta dengan baik pula.

Pertumbuhan ekonomi ini sangat dipengaruhi oleh pertumbuhan sektor industri, terutama industri minyak dan gas. Selama kurun waktu 2008-2011, pertumbuhan ekonomi dan juga pertumbuhan sektor industri pengolahan gas alam cair oleh PT Arun NGL cenderung menurun.

\section{Tabel 3}

Perkembangan Pertumbuhan Ekonomi di Kota Lhokseumawe Periode 2007-2015

\begin{tabular}{|c|c|}
\hline TAHUN & $\begin{array}{c}\text { Pertumbuhan } \\
\text { Ekonomi } \\
\mathbf{( \% )}\end{array}$ \\
\hline 2007 & 12,11 \\
\hline 2008 & 6,38 \\
\hline 2009 & 5,66 \\
\hline 2010 & 5,88 \\
\hline 2011 & 3,79 \\
\hline 2012 & 4,35 \\
\hline 2013 & 3,50 \\
\hline 2014 & 6,7 \\
\hline 2015 & 8,73 \\
\hline \multicolumn{2}{|c|}{ Sumber: Badan Pusat Statistik (BPS), 2016 }
\end{tabular}

Berdasarkan Tabel 3 dapat dilihat bahwa pertumbuhan ekonomi di tahun 2007 sebesar 12,11 \%. Kemudian pada tahun 2008 dan tahun 2009 pertumbuhan ekonominya menurun dari tahun sebelumnya. Kemudian di tahun 2010 pertumbuhan ekonominya kembali meningkat dari $5,66 \%$ menjadi $5,88 \%$. Selanjutnya pada tahun 2011 pertumbuhan ekonominya kembali menurun. Kemudian pada tahun 2012 pertumbuhan ekonominya meningkat kembali dari 3,79\% menjadi 4,35\%. Dan pada tahun 2013 pertumbuhan ekonominya kembali menurun dari $4,35 \%$ menjadi 3,50\%. Dan pada tahun 2014 dan 2015 pertumbuhan ekonominya kembali meningkat. Dengan demikian, pertumbuhan ekonomi yang terjadi di Kota Lhokseumawe dari tahun 20072015 bergerak secara fluktuatif.

\section{Pertumbuhan Penduduk}

Pertumbuhan penduduk merupakan jumlah penduduk baik bertambah maupun berkurang yang terdapat di suatu tempat yang berbeda dari tahun ke 
tahun. Biasanya pertumbuhan penduduk dipengaruhi oleh adanya kelahiran, kematian dan juga migrasi. Apabila jumlah kelahiran lebih banyak dibandingkan jumlah kematian maka secara otomatis jumlah penduduk di suatu tempat akan bertambah. Begitu juga sebaliknya apabila jumlah kematian lebih banyak daripada jumlah kelahiran maka jumlah penduduk di suatu tempat akan berkurang.

Perubahan jumlah penduduk semakin menurun biasanya disebabkan oleh adanya bencana alam, adanya perang dan lainnya. Apabila hal ini terjadi secara terus menerus dan tidak dapat dikendalikan dengan baik maka pertumbuhan ekonomi di suatu wilayah tersebut akan menurun.

Pada tahun 2014 pertumbuhan penduduk di Lhokseumawe tercatat sebanyak 3,01 persen. Di mana Kecamatan Banda Sakti adalah kecamatan yang memiliki pertumbuhan penduduk terbesar yakni sebesar 2,36 persen. Dimana sebelumnya, pada tahun 2013 pertumbuhan penduduk yang terbesar terdapat di Kecamatan Muara Dua.

\section{Tabel 4}

\section{Perkembangan Pertumbuhan Penduduk di}

Kota Lhokseumawe Periode 2007-2015

\begin{tabular}{|c|c|}
\hline TAHUN & $\begin{array}{c}\text { Pertumbuhan } \\
\text { Penduduk } \\
(\%)\end{array}$ \\
\hline 2007 & 1,24 \\
\hline 2008 & 1,03 \\
\hline 2009 & 0,68 \\
\hline 2010 & 7,49 \\
\hline 2011 & 2,29 \\
\hline 2012 & 2,70 \\
\hline 2013 & 1,21 \\
\hline 2014 & 3,01 \\
\hline 2015 & 2,11 \\
\hline
\end{tabular}

Berdasarkan Tabel 4 dapat dilihat bahwa pertumbuhan penduduk di tahun 2007 sebanyak 1,24\%. Kemudian pada tahun 2008 dan tahun 2009 pertumbuhan penduduknya menurun. Pada tahun 2010 pertumbuhan penduduknya kembali meningkat dari $0,68 \%$ menjadi $7,49 \%$. Pada tahun 2011 pertumbuhan penduduknya kembali menurun dari 7,49\% menjadi 2,29\%. Pada tahun 2012 pertumbuhan penduduknya kembali meningkat dari 2,29\% menjadi 2,70\%. Dan di tahun 2013 dan tahun 2015 pertumbuhan penduduknya kembali menurun dari tahun sebelumnya. Dapat disimpulkan bahwa pertumbuhan penduduk di Kota Lhokseumawe dari tahun 2007-2015 bergerak secara fluktuatif.

\section{Hasil Regresi Linier Berganda}

Tabel 5

Hasil Regresi Linier Berganda

\begin{tabular}{|c|rrrrr|}
\hline \hline Variable & Coefficient & Std. Error & t-Statistic & Prob. \\
\hline \hline C & 54.03851 & 0.838518 & 64.44530 & 0.0000 \\
\hline $\mathrm{X}_{1}$ & 0.442274 & 0.106963 & 4.134840 & 0.0001 \\
\hline $\mathrm{X}_{2}$ & 0.328103 & 0.139986 & 2.343835 & 0.0210 \\
\hline \hline R-squared & & & & \\
\hline Adjusted R-squared & 0.163790 & Mean dependent var & 57.63778 \\
\hline S.E. of regression & 2.809777 & Akaike info criterion & 4.931472 \\
\hline Sum squared resid & 828.9589 & Schwarz criterion & 5.005976 \\
Log likelihood & -263.2995 & Hannan-Quinn criter. & 4.961680 \\
\hline F-statistic & 10.28330 & Durbin-Watson stat & 0.186853 \\
\hline Prob(F-statistic) & 0.000083 & & & \\
\hline \hline
\end{tabular}

Sumber: Hasil penelitian, 2018 (data diolah)

Berdasarkan hasil regresi dari Tabel 5 diatas menunjukkan nilai constant (konstanta) adalah sebesar 54.03851, pertumbuhan ekonomi $\left(\mathrm{X}_{1}\right)$ adalah sebesar 0.442274 dan pertumbuhan penduduk $\left(\mathrm{X}_{2}\right)$ adalah sebesar 0.328103 . Adapun persamaan dapat ditulis sebagai berikut:

$\mathrm{Y}=\beta_{0}+\beta_{1} \mathrm{X}_{1}+\beta_{2} \mathrm{X}_{2}+e$

$Y=54.03851+0.442274 X_{1}+0.328103 X_{2}$

Adapun penjelasan persamaan model sebagai berikut:

1. Nilai konstanta $\left(\beta_{0}\right)$ adalah sebesar 54.03851, apabila pertumbuhan ekonomi dan pertumbuhan penduduk dianggap konstan (tetap) sebesar 0 , maka TPAK juga konstan sebesar 54.03851 persen.

2. Nilai Koefisien $\left(\beta_{1}\right)$ adalah sebesar 0.442274 , apabila pertumbuhan ekonomi meningkat sebesar 1 persen maka TPAK juga akan meningkat sebesar 0.442274 persen, dengan asumsi bahwa pertumbuhan penduduk dianggap konstan (tetap).

3. Nilai Koefisien $\left(\beta_{2}\right)$ adalah sebesar 0.328103, apabila pertumbuhan penduduk meningkat sebesar 1 persen maka TPAK juga akan meningkat sebesar 0.328103 persen, dengan asumsi bahwa pertumbuhan ekonomi dianggap konstan (tetap). 


\section{Uji Autokorelasi}

Uji autokorelasi dipakai untuk melihat adakah pada suatu model terdapat hubungan kesalahan pengganggu pada tahun sekarang dengan tahun sebelumnya atau t-1 (Ghozali, 2011). Pengujian terhadap autokorelasi dapat diuji dengan Metode Bruesch-Godfrey nama lain dari uji BG ini adalah uji langrange multiplier (LM test atau pengganda langrange). Apabila $\mathrm{Obs}^{*} \mathrm{R}$-squared < dari ChiSquare Table $\left(X^{2}\right)$ maka tidak ada terjadinya autokorelasi begitu juga sebaliknya apabila Obs*R-squared > dari Chi-Square Table $\left(X^{2}\right)$ maka ada terjadinya autokorelasi dilihat pada $\propto$ 5\% (Widarjono, 2013). Berikut ini merupakan hasil dari uji autokorelasi:

\section{Tabel 6}

\section{Hasil Uji Autokorelasi}

\begin{tabular}{l|ll|l|}
\hline \multicolumn{2}{|l|}{ Breusch-Godfrey Serial Correlation LM Test: } & \\
\hline \hline F-statistic & 233.6994 & Prob. F(2,103) & 0.0000 \\
\hline Obs*R-squared & 88.49786 & Prob.Chi-Square(2) & 0.0000 \\
\hline \hline
\end{tabular}

Sumber: Hasil Penelitian, 2018 (data diolah)

Berdasarkan Tabel 6 bahwa nilai $O b s * R$ squared sebesar 88.49786 dan nilai Chi-Square Table $\left(X^{2}\right)$ dengan derajat kepercayaan $5 \%$ dan $\mathrm{df}$ n-1 adalah sebesar 129.918. Karena nilai $O b s^{*} R$ squared $88.49786<$ dari Chi-Square Table $\left(X^{2}\right)$ 129.918, sehingga dapat disimpulkan model ini bebas dari uji autokorelasi atau tidak terjadinya autokorelasi.

\section{Uji Heteroskedastisitas}

Uji heteroskedastisitas merupakan suatu kondisi dimana semua gangguan yang terdapat dalam fungsi regresi yang ada tidak mempunyai varians yang sama. Jika ada varians yang sama maka hal itu dinamakan dengan heteroskedastisitas, dan jika ada varians yang beda maka dinamakan dengan homoskedastisitas (Ghozali, 2012). Untuk mengetahui ada tidaknya heteroskedastisitas dilakukan dengan melalui White Heteroskedastisitas pada program Eviews. Berikut ini hasil dari uji heteroskedastisitas:

\section{Tabel 7}

Hasil Uji Heteroskedastisitas

Heteroskedasticity Test: White

\begin{tabular}{l|ll|l}
\hline \hline F-statistic & 13.26573 & Prob. F(5,102) & 0.0000 \\
\hline Obs*R-squared & 42.55659 & Prob.Chi-Square(5) & 0.0000 \\
\hline Scaled explained SS & 40.26986 & Prob. Chi-Square(5) & 0.0000 \\
\hline \hline
\end{tabular}

Sumber: Hasil Penelitian, 2018 (data diolah)

Berdasarkan Tabel 7 bahwa nilai $O b s * R$ squared adalah sebesar 42.557 dan nilai ChiSquare Table $\left(X^{2}\right)$ dengan derajat kepercayaan 5\% dan df n-1 adalah sebesar 129.918. Karena nilai Obs*R-squared 42.557 < dari Chi-Square Table $\left(X^{2}\right)$ 129.918, disimpulkan bahwa model ini bebas dari uji heteroskedastisitas atau tidak terjadinya heteroskedastisitas.

\section{Uji Multikolinieritas}

Uji multikolinearitas bertujuan untuk menguji apakah di model regresi terdapat hubungan antara variabel bebas yang satu dengan variabel bebas yang lainnya (Ghozali, 2006). Uji multikolinieritas ilakukan dengan cara melihat nilai Variansi Inflation Factors (VIF) dari masingmasing variabel bebas terhadap variabel terikat. Apabila nilai VIF dibawah 10 dan tolerance value diatas 0,10 , maka model tersebut tidak terjadi multikolinieritas (Gudono, 2012). Berikut ini yaitu hasil dari uji multikolinieritas:

\section{Tabel 8}

\section{Hasil Uji Multikolinieritas}

\begin{tabular}{|c|c|c|c|}
\hline \hline \multirow{2}{*}{ Variable } & Coefficient & Uncentered & Centered \\
\hline \hline $\mathrm{X}_{1}$ & Variance & VIF & VIF \\
\hline $\mathrm{X}_{2}$ & 0.703112 & 9.618435 & NA \\
\hline $\mathrm{X}_{2}$ & 0.011441 & 7.314395 & 1.014510 \\
\hline \hline
\end{tabular}

Sumber: Hasil Penelitian, 2018 (data diolah)

Berdasarkan Tabel 8 menunjukkan bahwa nilai VIF pada variabel Pertumbuhan Ekonomi $\left(\mathrm{X}_{1}\right)$ dan Pertumbuhan Penduduk $\left(\mathrm{X}_{2}\right)$ adalah sebesar 1.014510. Diketahui nilai VIF dibawah 10, sehingga dapat dikatakan bahwa model ini bebas dari uji multikolinieritas atau tidak terjadinya multikolinieritas antara variabel independen atau bebas dalam model regresi. 


\section{Secara Parsial (Uji t)}

Menurut Gujarati (2003) uji t dipakai untuk menguji apakah ada atau tidaknya pengaruh antara variabel-variabel bebas terhadap variabel terikat secara individu atau parsial. Pengujian hipotesis terhadap koefisien regresi secara parsial dilakukan melalui uji t terhadap tingkat keyakinan 95\%, dan tingkat kesalahan $\propto=5 \%$ dengan ketentuan degree of freedom $(\mathrm{df})=\mathrm{n}-\mathrm{k}$, dimana $\mathrm{n}$ $=$ jumlah sampel, $\mathrm{k}=$ jumlah variabel.

Berdasarkan hasil pengujian yang ditunjukkan pada Tabel 5 diatas dapat dilihat bahwa pertumbuhan ekonomi $\left(\mathrm{X}_{1}\right)$ memiliki nilai $t_{\text {hitung }}$ sebesar 4.134840 dengan nilai signifikansi 0.0001 sementara nilai $\mathrm{t}_{\text {tabel }}$ dengan $(\mathrm{df})=\mathrm{n}-\mathrm{k}$ $(108-3=105)$ pada $\propto=0,05$ diperoleh nilai sebesar 1.65950. Maka $t_{\text {hitung }}>\mathrm{t}_{\text {tabel }}$ yaitu 4.134840 $>1.65950$, yang berarti terima Ha1 dan tolak $\mathrm{H}_{01}$. Dapat disimpulkan bahwa secara parsial pertumbuhan ekonomi berpengaruh secara signifikan terhadap TPAK di Kota Lhokseumawe.

Sedangkan variabel pertumbuhan penduduk $\left(\mathrm{X}_{2}\right)$ memiliki nilai thitung sebesar 2.343835 dengan nilai signifikansi 0.0210 sementara nilai $t_{\text {tabel }}$ dengan $(\mathrm{df})=\mathrm{n}-\mathrm{k}(108-3=105)$ pada $\propto=0,05$ diperoleh nilai sebesar 1.65950. Maka $t_{\text {hitung }}>\mathrm{t}_{\text {tabel }}$ yaitu $2.343835>1.65950$, yang berarti terima $\mathrm{H}_{\mathrm{a}}$ dan tolak $\mathrm{H}_{02}$. Sehingga dapat disimpulkan bahwa secara parsial atau secara individual pertumbuhan penduduk berpengaruh secara signifikan terhadap TPAK di Kota Lhokseumawe.

\section{Secara Simultan (Uji F)}

Menurut Ghozali (2005) uji F dipakai untuk menguji apakah ada atau tidaknya pengaruh antara variabel-variabel bebas secara bersamasama terhadap variabel terikat. Pengujian ini dilakukan melalui uji $\mathrm{F}$ atau uji secara simultan. Pengujian secara keseluruhan ini dilakukan dengan cara membandingkan nilai antara $F_{\text {hitung }}$ dan $F_{\text {tabel }}$ pada df1 = k-1 dan df2 = n-k pada derajat keyakinan $95 \%$ atau $\propto=0,05$.

Berdasarkan hasil pengujian yang ditunjukkan pada Tabel 5 diatas, bahwa nilai $F_{\text {hitung }}$ sebesar 10.28330 dengan nilai signifikansi 0.000083 pada taraf kepercayaan 95\%. Sedangkan nilai $\mathrm{F}_{\text {tabel }}$ dengan df1 = k-1 $(3-1=2)$ dan df $2=\mathrm{n}-\mathrm{k}$ $(108-3=105)$ pada derajat $95 \%$ atau $\propto=0,05$ diperoleh nilai sebesar 3.08. Maka $F_{\text {hitung }}>F_{\text {tabel }}$ yaitu $10.28330>3.08$, yang berarti menerima $\mathrm{H}_{\mathrm{a}}$ dan menolak $\mathrm{H}_{0}$. Sehingga disimpulkan bahwa secara simultan (bersama-sama) pertumbuhan ekonomi dan pertumbuhan penduduk berpengaruh secara signifikan terhadap TPAK di Kota Lhokseumawe.

\section{Koefisien Determinasi $\left(\mathbf{R}^{\mathbf{2}}\right)$}

Koefisien determinasi (Adjusted $\mathrm{R}^{2}$ ) dilakukan untuk mengetahui seberapa besar pengaruh antara variabel independen dalam menjelaskan variabel dependen. Yang termasuk nilai koefisien determinasi yaitu nilai dari nol sampai dengan satu. Dimana apabila nilainya yang dihasilkan mendekati satu yang artinya variabel independen hampir memberikan semua informasi yang diinginkan terhadap dugaan dari variabel dependennya (Ghozali, 2012).

Berdasarkan hasil pengujian pada Tabel 5 bahwa nilai $\mathrm{R}^{2}$ adalah sebesar 0.147863 $(14,7863 \%)$, yang artinya besarnya pengaruh pertumbuhan ekonomi dan pertumbuhan penduduk terhadap (TPAK) di Kota Lhokseumawe adalah sebesar 0.147863 (14,7863\%), sedangkan yang dipengaruhi oleh observasi variabel lain diluar penelitian ini adalah $0.852137(85,2137 \%)$.

\section{Koefisien Korelasi (R)}

Menurut Supranto (2009), koefisien korelasi adalah suatu langkah yang dilakukan untuk melihat seberapa kuat atau tidaknya pengaruh variabel bebas terhadap variabel terikat. Adapun cara yang dilakukan untuk melihat seberapa kuat atau tidaknya itu dilihat dari hasil yang diperolehnya, jika hasil yang diperolehnya mendekati angka 1 maka artinya pengaruh yang dimilikinya sangat kuat begitu juga sebaliknya.

Untuk mengetahui hubungan pertumbuhan ekonomi dan pertumbuhan penduduk terhadap (TPAK) di Kota Lhokseumawe dapat dilihat pada nilai R. Berdasarkan hasil pengujian pada Tabel 5 bahwa nilai $\mathrm{R}$ adalah $\mathrm{R}=\sqrt{\mathrm{R}}^{2}=\sqrt{0.147863}=$ 0.384530. sehingga dapat disimpulkan bahwa hubungan antara pertumbuhan ekonomi dan pertumbuhan penduduk terhadap (TPAK) di Kota Lhokseumawe berhubungan rendah secara positif 
karena nilai 0.384530 tidak mendekati positif 1 $(+1)$.

\section{Pengaruh Pertumbuhan Ekonomi Terhadap Tingkat Partisipasi Angkatan Kerja (TPAK) di Kota Lhokseumawe}

Dapat dilihat bahwa pertumbuhan ekonomi $\left(\mathrm{X}_{1}\right)$ memiliki nilai thitung sebesar 4.134840 dengan nilai signifikansi 0.0001 sementara nilai $t_{\text {tabel }}$ dengan $(\mathrm{df})=\mathrm{n}-\mathrm{k}(108-3=105)$ pada $\propto=0,05$ diperoleh nilai sebesar 1.65950. Maka $t_{\text {hitung }}>t_{\text {tabel }}$ yaitu $4.134840>1.65950$, yang berarti terima Ha1 dan tolak $\mathrm{H}_{01}$. Dapat disimpulkan bahwa secara sendiri-sendiri atau parsial pertumbuhan ekonomi berpengaruh secara signifikan terhadap TPAK di Kota Lhokseumawe. Hal ini sesuai juga dengan hasil penelitian pada Wisna Sarsi, dkk (2014), dimana PDRB memiliki pengaruh yang signifikan dengan arah yang positif terhadap TPAK.

\section{Pengaruh Pertumbuhan Penduduk Terhadap Tingkat Partisipasi Angkatan Kerja (TPAK) di Kota Lhokseumawe}

Dapat dilihat bahwa variabel pertumbuhan penduduk $\left(\mathrm{X}_{2}\right)$ memiliki nilai thitung sebesar 2.343835 dengan nilai signifikansi 0.0210 sementara nilai $\mathrm{t}_{\text {tabel }}$ dengan $(\mathrm{df})=\mathrm{n}-\mathrm{k}(108-3=$ 105) pada $\propto=0,05$ diperoleh nilai sebesar 1.65950. Maka $t_{\text {hitung }}>t_{\text {tabel }}$ yaitu $2.343835>$ 1.65950, yang berarti terima $\mathrm{H}_{\mathrm{a} 2}$ dan tolak $\mathrm{H}_{02}$. Dapat disimpulkan bahwa secara sendiri-sendiri atau parsial pertumbuhan penduduk berpengaruh secara signifikan terhadap TPAK di Kota Lhokseumawe. Hal ini sesuai juga dengan hasil penelitian pada penelitian Sayekti Suindah D (2014), dimana pertumbuhan penduduk memiliki pengaruh yang signifikan dengan arah yang positif terhadap TPAK.

\section{KESIMPULAN DAN SARAN}

\section{Kesimpulan}

Adapun dengan hasil penelitian yang telah dilakukan, sehingga diperoleh kesimpulan sebagai berikut:

1. Secara sendiri atau parsial pertumbuhan ekonomi berpengaruh positif dan signifikan terhadap TPAK di Kota Lhokseumawe periode 2007-2015.
2. Secara sendiri atau parsial pertumbuhan penduduk berpengaruh positif dan signifikan terhadap TPAK di Kota Lhokseumawe periode 2007-2015.

3. Secara serentak pertumbuhan ekonomi dan pertumbuhan penduduk berpengaruh positif dan signifikan terhadap TPAK di Kota Lhokseumawe periode 2007-2015.

\section{Saran}

Berdasarkan hasil penelitian dan kesimpulan diatas, maka penulis memberikan beberapa saran sebagai berikut:

1. Diharapkan kepada pemerintah agar lebih memperhatikan hal-hal yang berhubungan atau yang berpengaruh terhadap tingkat partisipasi angkatan kerja, dikarenakan dalam hal ini hasil penelitian telah membuktikan bahwa variabel pertumbuhan ekonomi dan pertumbuhan penduduk berpengaruh positif dan signifikan terhadap tingkat partisipasi angkatan kerja (TPAK) di Kota Lhokseumawe. Dengan demikian pihak pemerintah dapat memberikan kesempatan bagi mahasiswa/i yang lulusan sarjana atau tingkat sederajatnya dapat dengan mudah dalam mendapatkan suatu pekerjaan. Dengan demikian tingkat partisipasi angkatan kerjanya pun akan semakin meingkat.

2. Diharapkan bagi peneliti selanjutnya yang berminat mendalami tentang hal-hal yang mempengaruhi tingkat partisipasi angkatan kerja, agar dapat meneliti dan membahas dengan lebih baik lagi. Diharapkan juga dengan adanya penelitian ini nantinya dapat meningkatkan partisipasi angkatan kerja di suatu wilayah tersebut. Adapun dengan cara melihat serta mempelajari lebih lanjut mengenai hal-hal apa saja yang akan mempengaruhi besar kecilnya tingkat partisipasi angkatan kerja. Dengan demikian tingkat penggangguran yang ada di suatu wilayah sedikit demi sedikit dapat diatasi. 


\section{DAFTAR PUSTAKA}

Badan Pusat Statistik (BPS). (2012). Data Strategi BPS. Katalog BPS.

Badan Pusat Statistik (BPS). (2016). Kota Lhokseumawe Dalam Angka 2017. Katalog BPS.

D, S. S. (2014). Penduduk Dan Pengangguran: Sebuah Analisis Kependudukan Di Provinsi Jawa Timur. Jurnal Eba, 1(1), 14-33.

Ghozali, I. (2005). Aplikasi Analisis Multivariate. Badan Penerbit Universitas Diponegoro: Semarang.

Ghozali, I. (2006). Aplikasi Analisis Multivariate

Edisi Keempat. Badan Penerbit Universitas Diponegoro: Semarang.

Ghozali, I. (2011). Aplikasi Analisis Multivariate. Badan Penerbit Universitas Diponegoro: Semarang.

Ghozali, I. (2012). Aplikasi Analisis Multivariate. Universitas Diponegoro: Semarang.

Gudono, M. (2012). Analisis Data Multivariat

Edisi Kedua. BPFE: Yogyakarta.

Gujarati, D. (2003). Basic Econometric. McGraw-Hill: New York.

Jhingan, M. (2010). Ekonomi Pembangunan

Dan Perencanaan, Terjemahan. Rajawali

Pers: Jakarta.

Mankiw, N. G. (2013). Pengantar Ekonomi Makro. Salemba Empat: Jakarta.

Mulyadi. (2002). Ekonomi Sumber Daya Manusia Dalam Perspektif Pembangunan

Edisi Kesatu. Grafindo: Jakarta.

Mulyadi. (2003). Ekonomi Sumber Daya Manusia Dalam Perspektif Pembangunan Edisi kesatu. Grafindo: Jakarta.

Sarsi, W., Putro, T. S., \& Sari, L. (2014). Pengaruh Tingkat Upah Dan Pertumbuhan Ekonomi Terhadap Tingkat Partisipasi Angkatan Kerja Di Provinsi Riau. JOM FEKON, 1(2), 1-15.

Simanjuntak, P. J. (2000). Pengantar Ekonomi Sumber Daya manusia. LPFE: Jakarta.

Subandi. (2011). Ekonomi Pembangunan Edisi Pertama. Alfabeta: Bandung.

Sukirno, S. (2006). Makro Ekonomi Teori Pengantar Edisi Ketiga. Pusat Pengembangan Pendidikan Universitas: Jakarta.
Sukirno, S. (2007). Pengantar Teori Makro Ekonomi. PT Raja Grafindo: Jakarta.

Supranto, J. (2009). Statistik Teori Dan Aplikasinya Edisi Ketujuh. Erlangga: Jakarta.

Widarjono, A. (2013). Ekonometrika Pengantar Dan Aplikasinya Disertai Panduan Eviews Edisi Keempat. UUP STIM YKPN: Yogyakarta. 